\title{
Finding the Spirit of Elijah in the Story of Elisha and the Lost Axe Head: 2 Kings 6:1-7 in the Light of 2 Kings 2
}

\author{
RICKIE MOORE (LEE UNIVERSITY)
}

\begin{abstract}
Against a long-standing trend in biblical scholarship to demean and diminish the significance and purpose of the Elisha story of the lost axe head in 2 Kings 6:1-7, this paper shows this story's strategic purpose in relation to a central theological theme of the Elijah-Elisha complex and the entire Kings corpus. By pointing out the striking literary parallels and connections between this Elisha story and the story of Elisha's receiving the mantle of Elijah in 2 Kings 2, together with this latter story's central thematic role not only in the Elijah-Elisha materials but in the Kings narrative as a whole, the story of the lost axe head reveals the pivotal divine purpose of transacting spiritual succession from one generation to the next.
\end{abstract}

KEYWORDS: Elijah; Elisha; Sons of the Prophets; 1 \& 2 Kings; 2 Kings 2; 2 Kings 6:1-7; Generational Succession

Where is the spirit of Elijah, specifically, in the story of Elisha and the lost axe head? My title poses this question, and the following study proposes to answer it. In presenting this study, I hope to reveal a higher purpose for this short biblical narrative than has regularly been ascribed to it.

The story of the prophet Elisha recovering a lost axe head from the Jordan River in 2 Kings 6:1-7 has not occupied an especially distinguished place in the history of biblical interpretation. The novelty of the miracle of the floating of the iron axe head has given this story what little attraction it has gained. In critical scholarship this miracle account is rather lightly regarded by most as a fabricated legend designed to inflate the spiritual reputation of the prophet. ${ }^{1}$ As

* Submitted: 14/11/2018; peer-reviewed: 03/01/2019; accepted: 09/01/2019. Rickie Moore, Finding the Spirit of Elijah in the Story of Elisha and the Lost Axe Head: 2 Kings 6:1-7 in the Light of 2 Kings 2," 31 no. 3 (2018): 780-789. https://doi.org/ 10.17159/2312-3621/2018/v31n3a21.

1 Representative of this perspective is Burke O. Long, 2 Kings (Forms of the Old Testament Literature, Vol. X; Grand Rapids, MI: Eerdmans, 1991), pp. 79-81. Long says, "This narrative is a Prophet Legend, a story which chiefly portrays a wondrous deed or ideal virtue of an exemplary holy man" (p. 80). He also says that "one primary aim of this legend would have been to demonstrate the hero's marvellous power, and to inculcate attitudes of awe and reverence toward him" (p. 81). He sees this general purpose of the legend feeding into other purposes found in the larger literary setting, 
one scholar has put it, with this narrative there comes the "feeling that here the sacred Scripture degenerates to the level of the stories of the medieval saints and pagan magicians."2 In Pentecostal preaching and charismatic spirituality the story is taken more seriously, but only as an example of how God's miraculous intervention can suddenly turn any bad situation around. Either way, any greater theological purpose reaching appreciably beyond the mere claim of miraculous power, whether for the prophet or for God, has not been prominent. This paper will seek to show that this small story can be seen to serve a much larger theological function. Viewing 2 Kings 6:1-7 inter-textually in the light of a prime thematic thrust of the Elijah narratives generally and the culminating Elijah story of 2 Kings 2 in particular, this study suggests that this Elisha story about the lost axe head serves the key concern of these Elijah materials to see a divinely generated, life-empowering endowment passed from one generation to the next.

The axe head narrative is brief and compactly told as follows:

(1) Now the sons of the prophets said to Elisha, "See now, the place where we dwell with you is too small for us. (2) Let us go, please, to the Jordan and take there, each man a timber, and make for ourselves there a place to dwell." And he said, "Go." (3) Then one said, "Please consent and go with your servants." And he said, "I will go." (4) So he went with them, and they came to the Jordan and they cut down trees. (5) But as one was felling a beam, the iron axe head fell into

viz., enhancing Elisha's image as "powerful guide and helper" and Dtr's agenda of highlighting, by extension, "God's powers during the reign of Jehoram" (p. 81). Long says, "The incident is quite removed from the grander scope of international relations in chs 5 and 6:8-23. The tradition seems ... stylistically wooden and unimaginative" (p. 80). Also, see Richard Nelson, First and Second Kings (Interpretation; Atlanta: John Knox Press, 1987), 184-85. Nelson presents this story (grouped with others in 2 Kings 6-8:15) under the heading, "Stories of Prophetic Power". He begins his commentary on this story, "The story of the floating axe head (6:1-7) is something of an embarrassment for modern readers. The miracle seems both trivial and pointless" (p. 184). Cf. J. Robinson, The Second Book of Kings (Cambridge Bible Commentary; Cambridge: Cambridge University Press, 1976), 56-58, who flatly asserts, "This story is a legend" (p. 57). Robinson sees it as the kind of story common in the ancient world attaching to religious leaders, though he does concede that it is particularized here according to the special image of Elisha being promoted - one that involves remarkable power exercised for the sake of relieving the hardship of others.

2 Ronald S. Wallace, Elijah and Elisha: Expositions from the Book of Kings (Edinburgh: Oliver \& Boyd, 1957), 119. Wallace himself proceeds from this observation to his own attempt to see in the axe head story and two others (found in 2 Kings 4:38-44) "the possible significance of these three miracle stories" (p. 120). His primary idea about the significance of the axe head story has to do with how it shows that misfortunes that appear to upset the work of God's people can be "taken up by God and made to contribute to the building up of the Kingdom" (p. 125). 
the waters. And he cried out, "Oh, my master, it was borrowed?" (6) Then the man of God said, "Where did it fall?" He showed him the place. Then he cut down a stick and threw it there, and the iron floated. (7) And he said, "Take it up for yourself." So he reached out his hand and took it. ${ }^{3}$

Viewing this passage in relative isolation, as is typically done, one can easily reach the conclusion that this is a story or legend that intends to do little more than display or demonstrate the supernatural power of "the man of God". One could even find a reinforcement for this view in a subsequent story of Elisha that appears a couple of chapters later, where the king of Israel in 2 Kings 8:4 asks Elisha's servant Gehazi, "Tell me all the great things that Elisha has done." It is natural to see the previously recorded miracle of the axe head as one of those "great things" and the telling of this miracle as something arising from and arriving in the simple goal expressed here by the king, namely, just wanting to hear about the great things that Elisha has done. Yet it is interesting and perhaps telling that in this account of Gehazi informing the king about Elisha's great deeds, the event of this telling is overtaken by another event that creates a whole new context and occasion for realizing a new and greater purpose. Specifically, at the very moment when Gehazi is recounting how Elisha had restored a widow's son to life, in walks this very widow with her son in order to ask the king to restore a house and some land that they had recently lost through hardship. The king's purpose of wanting to hear about Elisha's power is now engulfed by a greater purpose, one that suddenly impinges upon the king's own power to act in line with Elisha's purpose, namely, to execute life-restoring action for this widow and her son (2 Kings 8:1-6).

In a similar way, the story of the lost axe head is not presented as an isolated telling but rather it is surrounded by a larger context that provides a framework for realizing a purpose for this small story that is larger than merely telling a great deed that Elisha has done. The nearby story of 2 Kings 2, the account of Elijah's ascension, has some particularly striking parallels to the story of the lost axe head, and noting these can begin to illuminate this larger purpose.

Consider these parallels: (1) Both 2 Kings 2 and 2 Kings 6:1-7 feature a trip to the region of the Jordan that (2) involves the prophet and the sons of the prophet. (3) In both stories the trip raises the prospect of the prophet and his band of followers being parted one from the other, and (4) in both instances we see sons of the prophet exhibiting a decided move to counter this prospect with a clear commitment to continuing with the prophet $(2: 2,4,6$, and $6: 3)$. Then in both stories this move on the part of the younger to continue being with the elder sets the stage for (5) a divine intervention that transacts an exchange between the

3 Translations of the biblical text are the author's own, unless otherwise noted. 
elder and the younger that (6) offers an empowering, supernaturally generated endowment for the younger to "take up" (2:13-14 and 6:7).

Of course, after these similarities are noted, one can notice a series of contrasts: (1) Most obviously, Elijah is the elder in 2 Kings 2 and Elisha is the elder in 2 Kings 6. (2) In the earlier story the elder is leaving, but in the latter, it is the sons of the prophets who initiate the leaving. (3) Elijah's departure in 2 Kings 2 is more permanent, for he is leaving his earthly life, whereas the departure of the sons of the prophets in 2 Kings 6 involves only a temporal relocation, a new place to live. ${ }^{4}$ And (4) in 2 Kings 2 Elijah resists his follower's expressed desire to go with him $(2: 2,4, \& 6)$, whereas in 2 Kings 6, Elisha responds positively to his followers' expressed desire that he "go with" them $(6: 3-4)$.

Yet all of these contrasts could be seen to come together with the noted similarities in a way that suggests a complementary relationship between these two stories around their shared focus on a divine intervention that transacts a passing of empowerment from one generation to the next. One could summarize the complementary relationship this way: (1) There is a passing of empowerment that goes from Elijah to Elisha in 2 Kings 2, and then from Elisha to his disciples in 2 Kings 6. (2) It is occasioned by the departure of the elder in the first story and by the departure of the children in the second. (3) It entails the ultimate departure of Elijah in the first story (i.e., a coming to the end of life) and a lessthan-final departure of the children in the second story (a coming of age). Correspondingly, (4) it involves the ultimate empowerment of a relinquished mantle in the first story and the immediate empowerment of a recovered tool in the second. The pivotal transition of Elisha between the two stories, particularly the shift in his role from being one of the "sons" in the first story to being the elder in the second, might even suggest that (5) what Elisha gained from his reluctant elder in the earlier episode has helped him to be readily giving to his children in the later episode.

All of these points of connection between the story of the ax head being raised up and the story of Elijah being taken up can serve to point up the significance of the former story, especially when the place of the latter story in its larger literary context is fully realized. 2 Kings 2 obviously occupies the central place between the Elijah and Elisha cycles, but, as George Savran has clearly pointed out, this narrative also comprises the literary midpoint of the entire Kings corpus. ${ }^{5}$ The major sections of the Kings material are laid out symmetrically, with the Elijah and Elisha stories forming the middle section

4 Perhaps going along with this difference in the extent of the two departures, Elijah's journey entails crossing the Jordan and traveling beyond it, whereas the sons of the prophets in 2 Kings 6 are intending to journey only to the Jordan.

5 George Savran, ' 1 and 2 Kings', in The Literary Guide to the Bible (R. Alter \& F. Kermode, eds., Cambridge, MA: Harvard University Press, 1987), 148-149. 
(1Kgs. 17-2 Kgs. 12), flanked on either side by sections that feature alternating coverage of the Northern and Southern Kingdoms (1 Kgs. 12-16 and 2 Kgs. 1317). These sections are themselves framed by matching outer sections that cover the unified kingdom of Solomon before the division of Israel on one side (1 Kgs 1-11) and the single remaining kingdom of Judah after the fall of the North on the other side (2 Kgs 18-25).

In addition to occupying the position of literary midpoint of Kings, 2 Kings 2 stands out in the literary corpus of Kings by another striking feature, as Richard Nelson has so helpfully observed. ${ }^{6}$ He notes how the material covering the divided kingdoms employs a literary pattern of shuttling back and forth between reigns of southern kings and northern kings in a chronologically staggered sequence. This weaves the history of the two kingdoms of Israel together in a way "the reader is unable to untangle". 7 The pattern turns on the use of literary formulas that respectively introduce and close the reign of each king, like the opening and closing of a file. All the files are covered in chronological order, except for the shifting that comes in the alternation between North and South, which produces the chronological staggering or overlapping effect. With this pattern, a file of one kingdom can be left open, while several files from the other kingdom are presented, all before the narrative shifts back to close the open file. This keeps everything moving forward but in an interlocking way. Everything is placed within the files, even at times some of the files of the other kingdom, with only two noteworthy exceptions, namely, the story of Athaliah's succession attempt in 2 Kings 11 and the story of Elisha's succession of Elijah in 2 Kings 2. The effect, so Nelson observes, is that, on the one hand, Athaliah's short-lived attempt to usurp the throne of David falls between and outside the southern files in a way that denies her a legitimizing place in the official southern sequence, and, on the other hand, the story of Elijah's ascension and Elisha's taking up of his mantle is placed between the files of two northern kings in a way that sets this "numinous" succession event "outside the run of ordinary time," succession from being placed under the reign of any human king.

Thus, the literary structure of the Kings corpus, both in its chiastically ordered macro-outline and in the highly exceptional interruptions in its regal filing system, serves to highlight the centrality and narrative significance of 2

6 Richard Nelson, "The Anatomy of the Book of Kings," Journal for the Study of the Old Testament 40 (1988): 39-48.

7 Nelson, “Anatomy," 44.

8 Ibid. Cf. Walter Brueggemann, 1 \& 2 Kings, Smyth \& Helwys Bible Commentary (Macon, GA: Smyth \& Helwys Publishing, 2000), 293, who comments, "chapter 2 stands between the two reigns, that is, outside them, outside 'royal time.' It is likely that the text is intentionally placed as it is, in order to suggest that the remarkable moment of prophetic transition is so odd and so exceptional that it cannot be held in royal time or understood in royal rationality." 
Kings 2. This story, then, to which the story of Elisha and the lost axe head is so thoroughly linked in its literary details, as previously noted, is no peripheral narrative. It has a distinguished place in the literary structure that is no doubt owing to its key thematic relationship with the entire Kings corpus. This important thematic relationship could be described as follows. Kings is a body of literature that treats a long line of leaders in succession. It begins with the story of Solomon's succession (1 Kings 1-2), after which there unfolds a lengthy and largely tragic saga of successions that eventually lead to the fall of the Israelite kingdoms, first the North (2 Kings 17) and finally the South (2 Kings 25). This overarching story line of royal failure has led Walter Brueggemann to suggest that the very title of the saga should be read "Kings?" - that is, "Kings" with a question mark. ${ }^{9}$ Yet this book stands beneath another title that categorizes the collection in which the book has been placed as "Prophets". And it is the dominating role of the prophets in this literature to predict and point up the royal failure and also to point the way to the ultimate success of all Israel beyond the failure. This is done not only by refusing to give up on the divine promise of the ultimate succession of David's house (2 Kings 11:36-39 and 25:27-30) but also, it would appear, by the preserving of the pilot light of ultimate success through the succession enacted and exhibited in the house of the prophets, especially as seen in the Elijah-Elisha stories and most explicitly in the central succession story of 2 Kings $2 .^{10}$

This central thematic function of 2 Kings 2 can be seen in sharper relief when viewed against the specific thematics of the Elijah narratives. As the study of Leah Bronner long ago recognized, the Elijah stories are dominated by the agenda of polemics against the cult of $\mathrm{Baal}^{11}$ — a fertility cult imported into Israel, both North and South, principally by the infectious influence of the royal house of the Omrides, specifically by Ahab and Jezebel in the North and by their daughter, Athaliah, by marriage to King Jehoram in the South. It was a cult that claimed Baal, not Yahweh, as the divine source of Israel's fertility, generativity and procreativity. Virtually every episode of the Elijah cycle can be seen as a counterpoint to the claims of Baalism. As Elijah's own name declares, "Yahweh is God", and this means Baal is not. The climactic confrontation on Mount Carmel makes this counterpoint in an explicit way, where the people exclaim, "Yahweh, He is God; Yahweh, He is God!" (1 Kgs 18:36-39). Every other

$9 \quad$ Walter Brueggemann, Hope within History (Atlanta: John Knox Press, 1987), 54.

10 See Savran, "1 and 2 Kings," 149, who comes close to this point in the following statement: "The midpoint [of the middle section of Kings] is 2 Kings 2. Although royal succession is frequently described in Kings, this is the only account of the transfer of the mantle of prophecy in the entire Bible. By placing the idea of prophetic continuity at the very centre of his work, the narrator emphasizes that as long as dynastic kingship continues, there will be a corresponding prophetic response."

11 Leah Bronner, The Stories of Elijah and Elisha as Polemics against Baal Worship (Leiden: EJ Brill, 1968). 
episode makes the counterpoint implicitly. Thus, when Elijah announces the cessation of the rains in Israel at the very beginning of the Elijah cycle $(1 \mathrm{Kgs}$ 17:1), the clear implication is that Yahweh, not Baal, controls the rains in all their fructifying and fertilizing power. When Elijah soon thereafter declares to the widow of Zarephath that her meagre remnants of meal and oil would not run out "until the day that Yahweh sends rain on the earth" (1 Kgs 17:14), it carries the implication that Yahweh, not Baal, not even the rain itself, is the ultimate generative source of the fruitfulness of the earth, even beyond the land of Israel. In the matter of the calling down of fire from heaven on Carmel and then again on the companies of fifty in the story of 2 Kings 1, there is the implication that Yahweh rather than Baal commands the thunderbolts that announce the rainstorm.

This dominant theme of Yahweh's triumph over Baal in the Elijah stories, then, presents Yahweh, not Baal, as the real God of fertility. In addition to Yahweh's powers of fertility in the world of nature, the fecundity of the land, which is the overt focus of the literature, I would suggest that there are also important, but largely unnoticed, indications in the Elijah cycle that Yahweh's powers of fertility are at work in restoring human generativity as well-another area where Baal's fertility claims had extended. This issue of Yahweh's power to restore human fruitfulness is centred and primarily manifested in and through the figure of Elijah and finally culminates, I would maintain, in the matter of Elijah's becoming and fulfilling his role as "father" to the "sons of the prophet", especially to Elisha, culminating, here again, in the strategic story of 2 Kings 2.

In teasing out this thematic strand of Elijah's fathering role in the Elijah cycle, I would begin with the reinforcing observation of how the entire canonical corpus of the Prophets ends with a reference that points up the lasting legacy of Elijah's role in this regard. This prophet whose own life culminated in a solemn intergenerational convergence and intersection with his spiritual son, becomes in the end an iconic figure associated for all time with the divine aim to "turn the hearts of elders to their children and the hearts of children to their elders" (Mal. 4.6; cf. Luk. 1.17).

It is remarkable that Elijah's canonical legacy arrives at this end in view of how the canonical presentation of Elijah begins. He is introduced in 1 Kings 17:1 only as "Elijah the Tishbite" without reference to any father. One can scarcely find another Old Testament character of such magnitude whose parentage and all genealogical antecedents are completely lacking. ${ }^{12}$ Is this a silence that says something? I would submit that it is telling us about a fathering

12 One could perhaps cite Daniel as a comparable example. His lack of genealogical identification in the book of Daniel might serve to register the force of the break in familial connection and native identity that the Babylonian captivity was deliberately aiming to carry out, as the story of Daniel 1 seems intent to show. 
deficit in Elijah's life that reflects a fathering deficit in Israel—one that Elijah is being raised up to redress. There is support for this in the words we later see Elijah speaking under the broom tree at the low point of his story: "Enough! Take my life now, O Yahweh, for I am no better than my fathers" (1 Kgs 18:4). Elijah is clearly indicating a fathering deficiency that reaches all the way down to the personal level for him. Yet this "fatherless" one is the very one whose story will culminate with Elisha's venerating words of appellation: "My father, my father, the chariots and horsemen of Israel!" (2 Kgs 2:12).

How does Elijah get from his fatherless introduction (1 Kgs 17:1) to this fatherly conclusion? The story of the widow of Zarephath and her son in 1 Kings 17: 8-24, I would suggest, conveys an important step in this significant thematic transition. This story contains two episodes. The first (vv. 8-16) involves Yahweh's provision in the arena of agricultural fertility, the miraculous supply of meal and oil, as previously noted. But the second is focused on Yahweh's power to raise up human offspring (vv. 17-24).

Elijah is introduced to the widow's son in the first episode (v. 12). This son, like Elijah, is fatherless and now dependent on this widow woman for his life. But in the second episode the identification between Elijah and this son goes to another level. The son falls sick and dies, his mother confronts "the man of God" with her tragedy, and Elijah says, "Give me your son" (v. 19a). And with words that seem to accentuate the transfer of the son's close connection from the mother to the prophet, we read, "then he took him out of her bosom, carried him into an upper room where he was staying, and laid him upon his bed" (v. 19b).

Still the identification between this man and this child goes one dramatic step further. In this upper room, we see a pivotal moment in Elijah's character development. For the first time in the Elijah cycle, we no longer see Elijah in the mode of the unflappable wielder of supernatural power. In a scene of desperation that virtually matches that of the mother, "he cried to Yahweh and said, 'O Yahweh, my God, have you brought calamity even to this widow, with whom I am staying, by killing her son?' Then he stretched himself out upon the child three times and cried to Yahweh and said, 'O Yahweh, my God, I beg you, let this child's life come into him again"” (vv. 20-21). Next we are told that Yahweh heard Elijah's voice, the child's breath, his nephesh, came into him again, and Elijah brought him down and gave him to his mother, saying, "Behold, your son lives" (vv. 22-23). If ever there was a scene that could represent the experience of becoming a spiritual parent, this surely is it.

The two episodes of Elijah's sojourn in Zarephath, then, can be seen to play a foreshadowing role in Elijah's unfolding mission. Even as the episode of the meal and oil foreshadows Yahweh's ecological triumph over Baal in Elijah's forthcoming ministry in Israel, the episode of Elijah's "delivery" of this child can be seen to presage his upcoming role in becoming a father, even a paragon 
of the restoration of fatherhood in Israel. One can see a literary correspondence in the broad thematic sequence of these two episodes and that of the Carmel and Horeb episodes that follow. The Carmel narrative leads up to a display of Yahweh's power through Elijah to send the rains that will replenish meal and oil throughout all Israel (1 Kgs 18:20-46; cf. 17:14), and the Horeb narrative that comes next features Elijah coming once again to the point of a desperate cry unto Yahweh that leads directly to the prophet's fatherly call to raise up Elisha, who will be first among the "sons of the prophet" (1 Kgs 19:1-18).

This pivotal moment on Horeb when God tells Elijah, "you shall anoint Elisha, son of Shaphat of Abel-Meholah, to be prophet in your place" (1 Kgs 19:16), has often been viewed as God's retraction of Elijah's commission, a divine decision to retire and replace Elijah for losing faith and despairing of life in his flight into the wilderness (19:4-14). Yet in terms of the thematics we have been tracing, this is not a moment of failure for Elijah but the moment that discloses his crowning success - success in terms of his destiny-defining mission of raising up a successor.

The destiny of Elijah that is defined on Horeb in 1 Kings 19 is fulfilled near the Jordan in 2 Kings 2, when he fully succeeds in being succeeded by Elisha. This fulfilment is tangibly signified by Elisha's taking up of his mantle. It is spiritually signified with Elijah's words that claim for Elisha a double portion, indeed the firstborn son's portion, of Elijah's spirit (2 Kgs 2:9-10) and also by the subsequent words of the "sons of the prophet", who, when seeing Elisha split the Jordan with Elijah's mantle, exclaim, "the spirit of Elijah rests on Elisha!" (2 Kgs 2:15).

It is the spirit of a father transferred to a son of the prophet who, in the spirit of his father, himself becomes a father to the sons of the prophet, and who accordingly and likewise comes to the end of his life and receives the same venerating appellation, "My father, my father, the chariots and horsemen of Israel!" (2 Kgs 13:14). Within this narrative framework in which the theme of intergenerational succession, so prominent in the Elijah stories, is carried forward, the story of Elisha and the lost axe head finds its significance and meaning.

\section{BIBLIOGRAPHY}

Bronner, Leah. The Stories of Elijah and Elisha as Polemics against Baal Worship. Leiden: EJ Brill, 1968.

Brueggemann, Walter. 1 \& 2 Kings. Smyth \& Helwys Bible Commentary. Macon, GA: Smyth \& Helwys Publishing, 2000.

Hope within History. Atlanta: John Knox Press, 1987.

Long, Burke O. 2 Kings, Forms of the Old Testament Literature, Vol. X. Grand Rapids, MI: Eerdmans, 1991.

Nelson, Richard. First and Second Kings, Interpretation Series; Atlanta, GA: John Knox Press, 1987. 
."The Anatomy of the Book of Kings," Journal for the Study of the Old Testament 40 (1988): 39-48.

Robinson, Joseph. The Second Book of Kings, Cambridge Bible Commentary; Cambridge: Cambridge University Press, 1976.

Savran, George. "1 and 2 Kings." Pages 148-149 in The Literary Guide to the Bible. Edited by R Alter \& F. Kermode. Cambridge, MA: Harvard University Press, 1987.

Wallace, Ronald S. Elijah and Elisha: Expositions from the Book of Kings. Edinburgh: Oliver \& Boyd, 1957.

Rickie Moore, Lee University, School of Religion, e-mail: rmoore@leeuniversity.edu. 